\title{
SIMPLIFIED RECOVERY PROCESS OF Ralstonia solanacearum-SYNTHESIZED POLYHYDROXYALKANOATES VIA CHEMICAL EXTRACTION COMPLEMENTED BY LIQUID-LIQUID PHASE SEPARATION
}

\author{
Karine L. Macagnan ${ }^{\mathrm{a}}$, Amanda A. Rodrigues ${ }^{\mathrm{a}}$, Mariane I. Alves ${ }^{\mathrm{b}}$, Lígia Furlan ${ }^{\mathrm{b}}$, Sônia M. Kesserlingh ${ }^{\mathrm{c}}$, Andréa B. Moura ${ }^{\mathrm{d}}$, \\ Patrícia D. de Oliveira ${ }^{a}$, Alan J. A. McBride ${ }^{a}$, Angelita da S. Moreira ${ }^{\mathrm{a}, \mathrm{b}, *}$ and Claire T. Vendruscolo ${ }^{\mathrm{a}, \mathrm{b}}$ \\ aNúcleo de Biotecnologia, Centro de Desenvolvimento Tecnológico, Universidade Federal de Pelotas, 96010-900, Pelotas - RS, Brasil

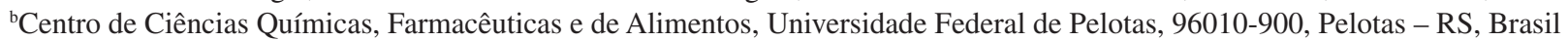 \\ 'Empresa PHB Industrial, 141500-000, Serrana - SP, Brasil \\ ${ }^{\mathrm{d}}$ Faculdade de Agronomia Eliseu Maciel, Universidade Federal de Pelotas, 96010-900, Pelotas - RS, Brasil
}

Recebido em 07/03/2016; aceito em 05/08/2016; publicado na web em 30/08/2016

\begin{abstract}
Poly (3-hydroxybutyrate) ( $\mathrm{P}(3 \mathrm{HB})$ ) is the most studied thermoplastic biopolymer belonging to the polyhydroxyalkanoate (PHA) family, the main features of which include rapid biodegradability and biocompatibility. The bioplastic recovery process is an important step during production and can directly influence the characteristics of PHAs. However, more efficient methods for the production of $\mathrm{P}(3 \mathrm{HB})$ are necessary to make it economically viable. The aim of the present study was to improve the standard, chloroformbased, extraction step for the recovery of $\mathrm{P}(3 \mathrm{HB})$. The polymer was produced using a Ralstonia solanacearum strain. The following parameters were improved in the recovery process: heating time, separation method (filtration or liquid-liquid phase separation), biomass state (fresh or dry cell concentrate) and the solvent:biomass ratio. By improving the chemical extraction of $\mathrm{P}(3 \mathrm{HB})$ we recovered $98 \%$ of the cumulative polymer and reduced the heating time by $75 \%$. Furthermore, we improved the separation process and developed an extraction solution that was faster and more economical.
\end{abstract}

Keywords: bioplastic; biopolymer; bioprocess; chloroform; poly (3-hydroxybutyrate).

\section{INTRODUCTION}

Conventional plastics derived from petroleum have been used for decades due to their strength, durability and low production costs. While plastics are a major benefit to society, their continued use is being questioned due to the serious impact plastics have on human health and the environment. ${ }^{1}$ Bioplastics produced by bacteria and plants are potential replacements for petrochemical derived plastics. Polyhydroxyalkanoates (PHAs) are bio-derived and biodegradable polymers that are used in the production of bioplastics. Poly (3-hydroxybutyrate) $(\mathrm{P}(3 \mathrm{HB}))$ is one of the most common PHAs and it is produced by a variety of organisms..$^{1-3}$ In bacteria, PHAs accumulate in the cytoplasm as insoluble polyester inclusion bodies that can represent up to $90 \%$ of the biomass. ${ }^{4}$ PHAs are energy storage metabolites and are produced in response to stress, usually under nutrient limiting conditions. ${ }^{5}$ While over 300 microorganisms can synthesize PHAs, production is usually limited to Ralstonia spp., Cupriavidus necator, Pseudomonas spp. and recombinant Escherichia coli. ${ }^{6-9}$ Ralstonia spp. tend to be more amenable to production on an industrial scale, demonstrating high yields and production rates, ${ }^{10}$ accumulating approximately $80 \%$ of its dry weight as polymer. ${ }^{11}$ The strain used in the present study, $R$. solanacearum $\mathrm{RS}$ was isolated from a cactus in Rio Grande do Sul (RS) and was characterized by $16 \mathrm{~S}$ rRNA sequeincing. ${ }^{12,13} R$. solanacearum is Gram-negative phytopathogen that causes bacterial wilt, ${ }^{14}$ a vascular disease of wide range of plants, including crops of high economic value, such as potatoes, tomatoes and tobacco belonging to the Solanum genus. ${ }^{15,16}$

With physical properties similar to polypropylene, including melting point, crystallinity, and glass transition temperature, $\mathrm{P}(3 \mathrm{HB})$ is the most studied and most used biopolymer for the production of bioplastics. ${ }^{6}$ However, the bioprocess used to produce these bioplastics can cost up to five times the price of synthetic plastics. The extraction

*e-mail: angelitadasilveiramoreira@gmail.com step is the most problematic and expensive, representing $50 \%$ or more of the total cost of production. ${ }^{3}$ Furthermore, the extraction process directly affects the quality of the recovered polymer. Therefore, research has focused on improving and minimizing the costs associated with extraction. Several extraction methods have been developed for the recovery of PHAs, including solvent extraction using chloroform, sodium hypochlorite digestion, surfactant, chelating enzymes and mechanical disruption. ${ }^{17-21}$ However, there is no published method for the extraction of PHAs or $\mathrm{P}(3 \mathrm{HB})$ that does not directly alter the characteristics of the recovered polymer. Although $\mathrm{P}(3 \mathrm{HB})$ is a commercial product, the problems associated with the extraction process have been not been resolved. Previous studies have focused on reducing damage to the polymer during the extraction step. ${ }^{21,22}$ However, the majority of these methods require extended heating and the use of chlorinated solvents, which are extremely toxic. Specific methodologies for the production of PHAs have been developed, but they are trade secrets or are protected by patents.

Recent research has focused on the microorganisms that are capable of producing PHAs or on their application..$^{1,7-9,13}$ Thus, there is an urgent need for research into the improvement of the polymer extraction process. We believe that this study will contribute to a more practical production, efficient recovery of $\mathrm{P}(3 \mathrm{HB})$, representing an important contribution to this field of study. The aim of this study was to improve the $\mathrm{P}(3 \mathrm{HB})$ extraction step using chloroform as the solvent and analysing the following variables: heating time, separation methodology, biomass state (fresh or dried concentrate) and the solvent:biomass ratio. Additionally, we evaluated the influence of the different extraction methodologies on the characteristics of the recovered $\mathrm{P}(3 \mathrm{HB})$.

\section{EXPERIMENTAL}

Microorganism

The $R$. solanacearum $\mathrm{RS}$ strain was supplied by the Bacteriology 
Laboratory, Eliseu Maciel Faculty of Agronomy, Federal University of Pelotas, RS, Brazil. The bacterium was lyophilised and stored at $-80{ }^{\circ} \mathrm{C}$, or sub-cultured monthly on nutrient agar (NA), ${ }^{23}$ composed of (in $\mathrm{g} \mathrm{L}^{-1}$ ) peptone, $5.0 \mathrm{~g}$; glucose, $5.0 \mathrm{~g}$; yeast extract, $1.0 \mathrm{~g}$; meat extract, $3.0 \mathrm{~g}$; and agar, $15.0 \mathrm{~g}$ and stored at $4{ }^{\circ} \mathrm{C}$.

\section{Production of $\mathrm{P}(3 \mathrm{HB})$}

$\mathrm{P}(3 \mathrm{HB})$ production was carried out in two steps: 1) Starter culture production, $R$. solanacearum $\mathrm{RS}$ was inoculated onto NA and incubated at $28{ }^{\circ} \mathrm{C}$ for $72 \mathrm{~h}$. The colonies were recovered from the NA plate and resuspended in $40 \mathrm{ml}$ yeast malt (YM) ${ }^{24}$ culture medium that was used to inoculate $160 \mathrm{ml} \mathrm{YM}$ in $500 \mathrm{ml}$ Erlenmeyer finned flasks. The culture was grown at $28{ }^{\circ} \mathrm{C}, 150$ $\mathrm{rpm}$ for $24 \mathrm{~h}$ on an orbital shaking incubator. The starter culture was used for 2) Accumulation/production of $\mathrm{P}(3 \mathrm{HB}), 160 \mathrm{ml}$ of F4 mineral production medium (composed of (in $\mathrm{g} \mathrm{L}^{-1}$ ) glucose, $40.0 \mathrm{~g}$; urea, $3.0 \mathrm{~g}$; citric acid, $0.2 \mathrm{~g}$; sodium citrate, $4.0 \mathrm{~g}$; and 1.0 $\mathrm{ml}$ trace element solution $\left(\mathrm{MgSO}_{4} 0.2 \mathrm{~g} ; \mathrm{CaCl}_{2}, 0.01 \mathrm{~g} ; \mathrm{Na}_{2} \mathrm{MoO}_{4}\right.$, $0.005 \mathrm{~g} ; \mathrm{Z}_{\mathrm{n}} \mathrm{SO}_{4}, 0.1 \mathrm{~g} ; \mathrm{FeCl}_{3}, 0.05 \mathrm{~g}$ ) was inoculated with $40 \mathrm{ml}$ of the starter culture in $500 \mathrm{ml}$ Erlenmeyer finned flasks and incubated at $28{ }^{\circ} \mathrm{C}, 200 \mathrm{rpm}$ for $72 \mathrm{~h}$.

\section{Evaluating the presence of lipophilic bodies}

Lipophilic bodies were detected using the Sudan Black staining method as described previously. ${ }^{25}$ Samples of $R$. solanacearum were fixed on glass slides and stained with Sudan Black dye $\left(0.3 \% \mathrm{w} \mathrm{v}^{-1}\right)$ for $10 \mathrm{~min}$, the slides were rinsed with xylene and water, dried with absorbent paper and stained with $0.5 \%$ safranin dye for $15 \mathrm{~s}$, washed with water and allowed to dry. The presence of lipophilic granules was visualised by light microscopy using an immersion lens.

\section{Determination of equivalency between fresh and dry cell concentrates}

Following the accumulation step for $\mathrm{P}(3 \mathrm{HB})$ production, the bacteria were harvested by centrifugation $(10,000 \times \mathrm{g}$ for $15 \mathrm{~min})$, the fresh cell concentrate (FCC) was resuspended in $0.89 \%$ saline solution, and the biomass was recovered $(10,000 \times \mathrm{g}$ for $10 \mathrm{~min})$. The amount of insoluble $\mathrm{P}(3 \mathrm{HB})$ in the $\mathrm{FCC}$ was determined by gravimetry. The dry cell concentrate (DCC) was obtained by drying the FCC at $56{ }^{\circ} \mathrm{C}$. To compare the quantity of $\mathrm{P}(3 \mathrm{HB})$ in the $\mathrm{FCC}$ compared to the DCC, triplicate FCC samples $(1 \mathrm{~g})$ were dried at $56{ }^{\circ} \mathrm{C}$, after reaching a constant weight the FCC/DCC ratio was calculated.

\section{Extraction of the polymer}

Improvement of the extraction time and cellular residue separation/extraction solution

The extraction step was performed using a chloroform:DCC ratio of 40:1 $\left(\mathrm{v} \mathrm{w}^{-1}\right)$. The sample was heated in a glass test tube in a water bath at $58{ }^{\circ} \mathrm{C}^{26,27}$ for $15,30,60,90$ and $120 \mathrm{~min}$. The cell residue was separated from the extraction solution using two methods: (1) Filtration through quantitative filter paper, the polymer was transferred to a covered Petri dish, and stored in a gas exhaust hood for slow solvent evaporation and biofilm formation; (2) Liquid-liquid phase separation based on differences in polarity. The sample was transferred to a separator funnel with 40 parts of distilled water, gently agitated and the phases were allowed to separate for $5 \mathrm{~min}$. The organic phase was transferred to a covered Petri dish and stored in a gas exhaust hood for slow evaporation of the solvent and biofilm formation.
Improvement of the biomass state (FCC or DCC) and solvent ratio

To improve the biomass state (FCC or DCC) and the solvent ratio, we used a heating time of $30 \mathrm{~min}$ and a cell residue separation/extraction solution using liquid-liquid phase separation. The extraction was performed using the following chloroform:biomass ratios: 40:1; 20:1 and 10:1 ( $\left.\mathrm{v} \mathrm{w}^{-1}\right)$ and either the FCC or the DCC. To evaluate the efficiency of the primary extraction step, a secondary extraction was performed by adding solvent to the aqueous phase fraction from the primary extraction. The remainder of the extraction step was carried out as described for the primary extraction step.

\section{Quantification of $\mathrm{P}(3 \mathrm{HB})$ accumulation by gas chromatography (GC)}

GC was used to determine the percentage of $\mathrm{P}(3 \mathrm{HB})$ accumulation in relation to the biomass. Methanolysis was carried out as described previously ${ }^{28}$ with modifications..$^{29} 10 \mathrm{mg}$ of the DCC was resuspended in $2 \mathrm{ml}$ of acidified methanol (methanol:sulphuric acid, $85: 15 \mathrm{v} \mathrm{v}^{-1}$ ) containing benzoic acid $0.4 \mathrm{~g} \mathrm{~L}^{-1}$ (internal standard) and $2 \mathrm{ml}$ of chloroform. The sample was incubated at $100{ }^{\circ} \mathrm{C}$ for 140 min, transferred to an ice bath and $1 \mathrm{ml}$ of distilled water was added. The sample was incubated at $25^{\circ} \mathrm{C}$ for $24 \mathrm{~h}$ and the cell residue was removed by decanting. The lower organic phase contained the ester solubilized in chloroform. The GC analysis was performed using a Shimadzu GC 17A, equipped with a DB WAXetr column (30 m x $0.25 \mathrm{~mm} \times 0.25 \mathrm{~mm}$ ) and a flame ionization detector. The carrier gas was hydrogen $\left(1 \mathrm{ml} \mathrm{min}^{-1}\right)$. The initial temperature was $80^{\circ} \mathrm{C}$ for 1 $\min$, increased $\left(11^{\circ} \mathrm{C} \mathrm{min}{ }^{-1}\right)$ to $200{ }^{\circ} \mathrm{C}$, for $4 \mathrm{~min}$. A $1 \mu \mathrm{l}$ sample was manually injected into the GC. The injector and detector temperatures were set at 260 and $280{ }^{\circ} \mathrm{C}$, respectively. Quantitative analysis was performed by the internal standardization method using benzoic acid as recommended by the manufacturer.

\section{Determination of yield polymer recovery processes}

After the extraction steps the biofilms were weighed to calculate the yield, which was expressed as a percentage. The following equation (1) was used to determine the yield:

$$
\% \mathrm{Y}=(\mathrm{P} 1 \div \mathrm{P} 2) \times 100
$$

where $\mathrm{P} 1$ is the total weight of the recovered biofilm and $\mathrm{P} 2$ is the accumulation of polymer in the cell concentrate. All averages were compared and analysed statistically by the Tukey test using the Statistix 9 program, $\mathrm{p}<0.05$ was considered significant.

\section{$\mathbf{P}(3 \mathrm{HB})$ characterization}

\section{Fourier transform infrared spectroscopy (FTIR)}

The polymeric film was dissolved in chloroform and the standard $\mathrm{P}(3 \mathrm{HB})$ was mixed with $\mathrm{KBr}$ to obtain tablets. To manufacture the tablets, $1 \mathrm{mg}$ of sample was dissolved in $1 \mathrm{~mL}$ of chloroform. IR spectra were obtained on a Fourier transform spectrometer Model Shimadzu IR Prestige 21. The images were acquired within a range of $4500-500 \mathrm{~cm}^{-1}$ with a resolution of $4 \mathrm{~cm}^{-1}$, as described previously. ${ }^{30}$

\section{Differential scanning calorimetry (DSC) and thermal gravimetric analysis (TGA)}

DSC and TGA analyses were performed using a Perkin Elmer Pyris 6. The DSC analysis $\backslash$ temperatures ranged from $20-200{ }^{\circ} \mathrm{C}$, increasing at a rate of $10{ }^{\circ} \mathrm{C} \mathrm{min}^{-1}$, and a nitrogen atmosphere with a flow rate of $20 \mathrm{ml} \mathrm{min}^{-1}$. To check the influence of heat on the 


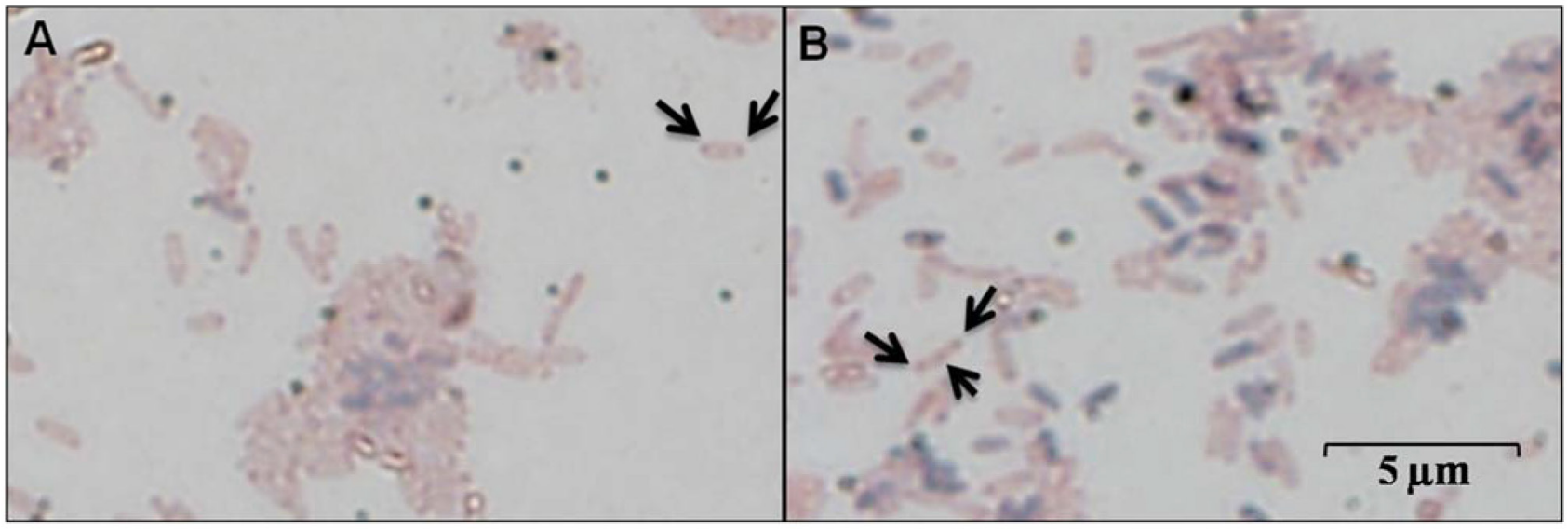

Figure 1. R. solanacearum RS cultivated for 24 h, stained with Sudan Black and viewed with an immersion lens with optical microscopy. It was possible to identify (A) R. solanacearum RS bacterial cells containing two lipophilic granules or (B) three lipophilic granules

samples, the crystalline melting temperatures (Tm) were analysed during the first heating cycle. However, in order to eliminate the thermal history of the material, the Tm were determined in a second heating cycle. The degree of crystallinity $(\mathrm{Xc})$ was determined from the melting enthalpy $(\Delta \mathrm{Hm})$ of the sample and was compared to that of pure $\mathrm{P}(3 \mathrm{HB})\left(\Delta \mathrm{Hm}=146 \mathrm{~J} \mathrm{~g} \mathrm{~g}^{-1}\right) .{ }^{31}$ To check the thermal stability [degradation onset temperature (Tonset) and maximum degradation temperature (Tpeak)] of the extracted polymers, the samples were heated from 30 to $500{ }^{\circ} \mathrm{C}$ at a rate of $10^{\circ} \mathrm{C} \mathrm{min}^{-1}$ under an atmosphere of nitrogen with a flow rate of $50 \mathrm{ml} \mathrm{min}^{-1}$.

\section{Gel Permeation Chromatography (GPC)}

The molar mass of the polymers was estimated by GPC analysis. The assay was developed by analysts at PHB Industrial SA (Serrana, SP, Brazil) and is not commercially available. We used the following Waters GPC equipment and accessories: 1515 isocratic pump, column heater, 717 plus autosampler, 2414 refractive index detector and Styragel columns $\left(10^{3}, 10^{4}, 10^{5}\right.$ and $10^{6} ; 7.80 \times 300$ $\mathrm{mm})$. The samples were solubilized in chloroform, filtered through a $0.45 \mu \mathrm{m}$ membrane and spiked with toluene as a peak marker prior to injection. The mobile phase was HPLC analytical grade chloroform.

\section{RESULTS AND DISCUSSION}

\section{Evaluation of lipophilic bodies}

A sample of $R$. solanacearum $\mathrm{RS}$ inoculum was stained and viewed under an optical microscope immersion lens, coupled with a camera and recorded photographically to determine the presence of lipophilic bodies, Figure 1. Sudan Black B is a basic dye that acts by diffusing into the bacteria and combining with acidic groups in lipophilic bodies, such as PHA inclusion bodies, staining them bluish-black in colour. ${ }^{25}$ The presence of stained inclusion bodies when viewed by microscopy indicates the accumulation of PHAs. ${ }^{32}$ The location and appearance of the stained inclusion bodies in the bacteria corresponded to $\mathrm{P}(3 \mathrm{HB})$ accumulation as previously reported in the literature for Ralstonia spp. ${ }^{32}$ The presence of two granules, one at each pole of the cell, is associated with the early stages of PHA accumulation, ${ }^{33}$ in several bacteria, including: Xanthobacter autotrophicus, Caryophanon latum, Rhodospirillum rubrum, R. eutropha and recombinant $E$. coli. It was suggested that granule formation occurred near the site of septum formation during cell division. The presence of a third granule, as observed in our study, typically occurs in the central region of the bacteria. ${ }^{30}$

\section{Extraction of the polymer}

Improvement of extraction time and cell residue/extraction solution separation

The $\mathrm{P}(3 \mathrm{HB})$ produced in the present study was recovered by filtration or liquid-liquid phase separation. The highest yields were obtained using liquid-liquid phase separation, regardless of the heating time, see Figure 2. For the liquid-liquid separation method, the highest yield $(96.8 \% \pm 2.0)$ was obtained with a heating time of $30 \mathrm{~min}$, followed by $15 \mathrm{~min}(77.2 \% \pm 1.7)$. These heating times represent a reduction of $75 \%$ and $87.5 \%$, respectively, compared to the standard heating time of $120 \mathrm{~min} \cdot{ }^{26,27}$ As heating time increased, the yield was reduced: 60,90 and 120 min resulted in $69.0 \% \pm 2.4$, $68.2 \% \pm 1.6$ and $66.9 \% \pm 2.2$ recovery, respectively, and there was no significant difference in yield. Using the filtration methodology, the yield was significantly lower: $45.2 \% \pm 1.9,48.9 \% \pm 0.7,52.2 \pm$ $0.7,52.8 \% \pm 0.2$, and $49.5 \% \pm 0.8$ for heating times of $15,30,60$, 90 and $120 \mathrm{~min}$, respectively.

The low yield observed with the filtration separation method is likely due to adsorption of $\mathrm{P}(3 \mathrm{HB})$ to the filter paper. This interaction between PHAs and cellulose was previously observed and is being

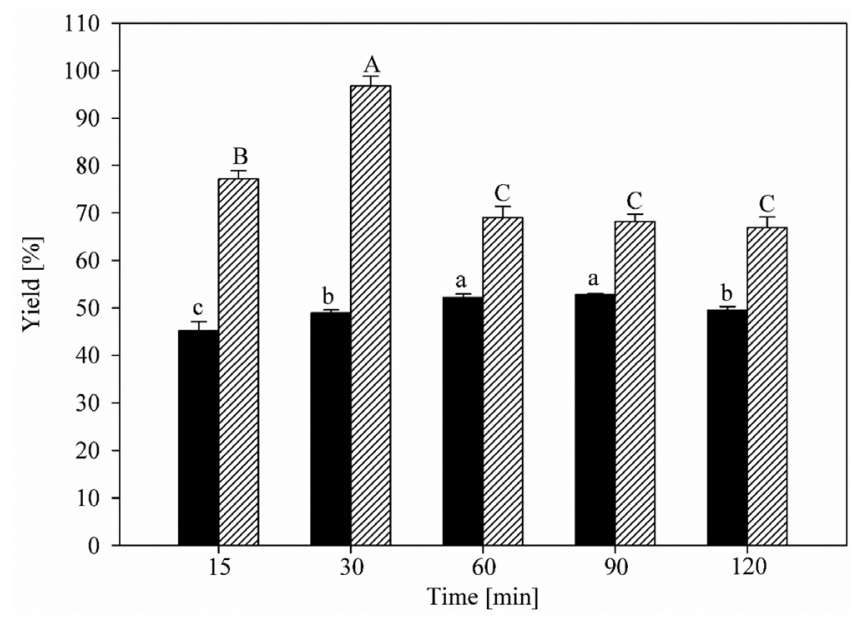

Figure 2. Comparison of two different separation methods for improving $P(3 H B)$ extraction and the heating times used. The average \% yield of $P(3 H B)$ recovered by the filtration method (solid columns) and the liquid-liquid phase separation method (hatched columns) at different heating times are shown, the error bars represent the standard deviation from the mean. Different lower and uppercase letters indicate a significant difference between the means, Tukey test $p<0.05$ 
exploited in the manufacture of hybrid materials, e.g. cardboard waterproofing. ${ }^{34}$ Of note, $\mathrm{P}(3 \mathrm{HB})$ yield was not proportional to the heating time during the extraction step. The reduction in yield associated with increased heating time was probably due to polymer degradation.

\section{Improvement of $\mathrm{P}(3 \mathrm{HB})$ biomass state (FCC or DCC) and solvent ratio}

Following the observation that the highest $\mathrm{P}(3 \mathrm{HB})$ yield was obtained using the liquid-liquid phase separation method and a heating time of $30 \mathrm{~min}$, the optimal biomass state (FCC or DCC) and solvent ratio were determined, see Figure 3 . The $\mathrm{P}(3 \mathrm{HB})$ yields obtained for the DCC were $41.8 \% \pm 9.9,57.9 \% \pm 8.8$ and $98 \% \pm 1.6$ for solvent ratios of 10:1, 20:1 and 40:1, respectively. To check for the presence of unrecovered $\mathrm{P}(3 \mathrm{HB})$ following the primary extraction, a secondary extraction was performed. Thus resulted in $21.7 \% \pm 3.5,8.8 \% \pm 2.8$ and $1.4 \% \pm 0.8$ polymer yields at ratios of $10: 1,20: 1$ and $40: 1$, respectively. The yield was directly proportional to the solvent:biomass ratio used, and 40:1 gave the best yield with the DCC. A secondary extraction was unnecessary using these conditions.

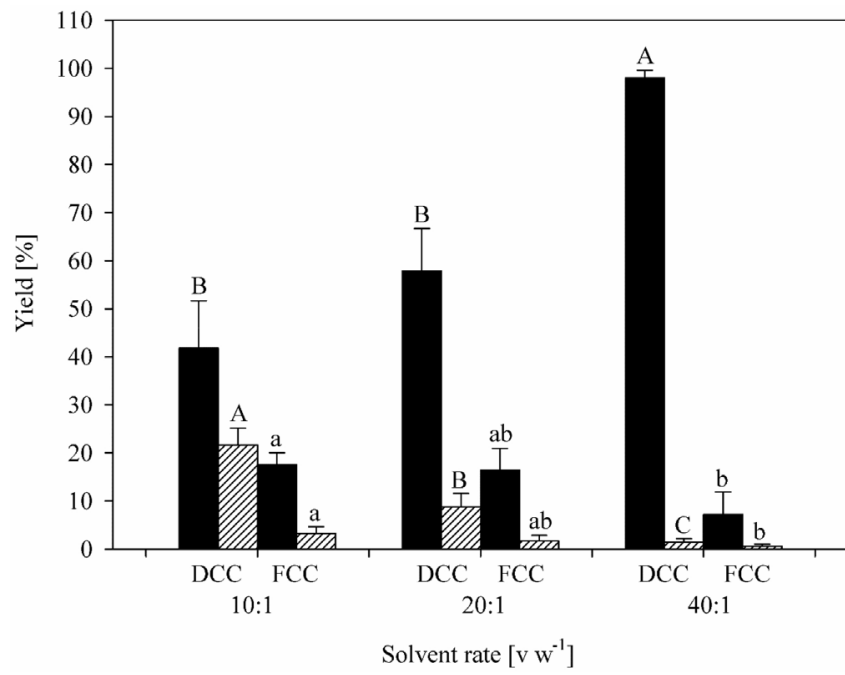

Figure 3. $P(3 H B)$ yields from the DCC and the FCC varied with solvent ratios used. The yields from the primary (solid column) and secondary (hatched column) extractions using either the DCC or the FCC are shown, the error bars represent the standard deviation from the mean. Different upper and lowercase letters represent a significant difference between the means, Tukey test, $p<0.05$

As a heating or drying step means higher energy costs, therefore we evaluated the recovery of $\mathrm{P}(3 \mathrm{HB})$ directly from the FCC. However, the highest yield was low, $17.6 \% \pm 2.5$, even though it was obtained using the lowest chloroform:biomass ratio, 10:1, the other yields were $16.4 \% \pm 4.6$ and $7.2 \% \pm 4.7$ for the $20: 1$ and $40: 1$ ratios, respectively. A secondary extraction did not improve the recovery of $\mathrm{P}(3 \mathrm{HB})$, the yields were $0.6 \% \pm 0.4,1.7 \% \pm 1.2$ and $3.3 \% \pm 1.3$ for solvent ratios of 40:1, 20:1 and 10:1, respectively. Comparing the DCC to the FCC showed that $1 \mathrm{~g}$ of DCC was equivalent to $3.18 \mathrm{~g}$ of $\mathrm{FCC}$ in terms of $\mathrm{P}(3 \mathrm{HB})$ yield. If we correct for equivalency between the DCC and the FCC, the highest yield for the FCC were equivalent to $56.0 \%$, at a 10:1 solvent ratio. However, these yields were still significantly lower than those of the DCC, $98 \%$ at a solvent:biomass ratio of 40:1.

Increasing the solvent:biomass ratio improved the breakdown of the emulsion formed by the addition of water during the extraction process. This allowed the formation of defined phases during separation, characterized by an aqueous phase containing cellular residue (more polar) and a chloroform extraction or organic phase (less polar).
We did not evaluate the impact of different solvent:biomass ratios on extractions from the FCC.

\section{Evaluating solvent use in the secondary extraction}

Towards minimising solvent use for the secondary extraction, we evaluated decreasing amounts of solvent and the impact on $\mathrm{P}(3 \mathrm{HB})$ recovery. The primary extraction yielded $97.8 \% \pm 1.2$ and $97.3 \% \pm$ 1.5 recovery of $\mathrm{P}(3 \mathrm{HB})$ followed by $1.3 \% \pm 0.8$ and $2.1 \% \pm 0.9$ after the secondary extraction at solvent ratios of $20: 1$ and 40:1, respectively. There was no significant improvement with increased solvent use. It was not possible to perform the secondary extraction with a solvent ratio of 10:1 due to emulsion formation, which prevented the separation of the organic and inorganic phases.

\section{Characterization of recovered $\mathrm{P}(3 \mathrm{HB})$}

\section{Fourier transform infrared spectroscopy (FTIR)}

The chemical composition of the biofilms of the recovered polymers was determined, see Table 1 . All of the spectra evaluated showed the characteristic vibrational frequencies for $\mathrm{P}(3 \mathrm{HB})$. The characteristic FTIR bands identified in the $\mathrm{P}(3 \mathrm{HB})$ produced in this study was in agreement with those reported in the literature. ${ }^{30,35,36}$

Table 1. Main vibrational frequencies for the recovered $\mathrm{P}(3 \mathrm{HB})$

\begin{tabular}{cccc}
\hline $\begin{array}{c}\text { Functional } \\
\text { group }\end{array}$ & $\begin{array}{c}\text { Wave Number } \\
\left(\mathrm{cm}^{-1}\right)\end{array}$ & $\begin{array}{c}\text { Vibrational } \\
\text { mode }\end{array}$ & Reference \\
\hline$-\mathrm{CH}_{3}$ & 2972 & $v_{\mathrm{as}}$ & 37 \\
$-\mathrm{CH}_{3}$ & 2872 & $v_{\mathrm{s}}$ & 37 \\
$-\mathrm{CH}_{2}$ & 2933 & $v_{\mathrm{as}}$ & 38 \\
$-\mathrm{CH}_{2}$ & 2853 & $v_{\mathrm{s}}$ & 38 \\
$-\mathrm{C}=\mathrm{O}$ & $1721-1727$ & $v$ & 39 \\
$-\mathrm{CH}_{2}$ & $1454-1459$ & $\delta_{\mathrm{s}}$ & 37 \\
$-\mathrm{CH}_{3}$ & 1378 & $\delta_{\mathrm{s}}$ & 37 \\
$-\mathrm{C}-\mathrm{O}$ & $1300-1000$ & $v$ & 39 \\
\hline
\end{tabular}

${ }^{a}$ Experimentally obtained values, $v$ : stretching; $\delta$ : deformation; s: symmetric; as: asymmetric.

\section{Differential scanning calorimetry (DSC) and thermal gravimetric analysis (TGA)}

Although the $\mathrm{P}(3 \mathrm{HB})$ samples produced in this study had a higher melting temperature $\left(170-175^{\circ} \mathrm{C}\right)$ than those commercially available from Sigma-Aldrich $\left(144^{\circ} \mathrm{C}\right)$ and Biocycle $\left(166^{\circ} \mathrm{C}\right)$, the values fell within the expected temperature range for $\mathrm{P}(3 \mathrm{HB})$, see Table 2. Melting temperatures have been reported to vary from 131$180{ }^{\circ} \mathrm{C}$, with an average of approximately $160{ }^{\circ} \mathrm{C} .{ }^{30,40-43}$ There was no relationship between the observed melting temperatures and the solvent:biomass ratios used in this study.

$\mathrm{P}(3 \mathrm{HB})$ is generally characterised as a semi-crystalline $(60-80 \%$ crystallinity), hard and brittle material, limiting its application. ${ }^{44}$ However, there are reports of 42 to $50 \%$ crystallinity for $\mathrm{P}(3 \mathrm{HB})$ produced by Bacillus megaterium and $27-45 \%$ for Pseudomonas spp. ${ }^{30,45}$ In the present study, the crystallinity of the $\mathrm{P}(3 \mathrm{HB})$ recovered from the DCC ranged from $37-63 \%$. The $\mathrm{P}(3 \mathrm{HB})$ with the lowest crystallinity was recovered from the FCC at a solvent ratio of 20:1, however the use of FCC in the extraction process resulted in a low yield (18\%). The extraction conditions with the highest yield (98\%: DCC, solvent ratio 40:1) produced $\mathrm{P}(3 \mathrm{HB})$ with $52 \%$ crystallinity. Reducing the solvent ratio to $10: 1$ during extraction resulted in a $\mathrm{P}(3 \mathrm{HB})$ with the same crystallinity, but with a lower yield $(42 \%)$. The crystallinity of the $\mathrm{P}(3 \mathrm{HB})$ samples produced in the present were 
Table 2. Characteristics of the $\mathrm{P}(3 \mathrm{HB})$ produced in this study compared to commercially available $\mathrm{P}(3 \mathrm{HB})$

\begin{tabular}{|c|c|c|c|c|c|c|}
\hline $\mathrm{P}(3 \mathrm{HB})$ Samples $^{\mathrm{a}}$ & $\mathrm{T}_{\mathrm{m}} 1^{\mathrm{b}}\left({ }^{\circ} \mathrm{C}\right)$ & $\mathrm{T}_{\mathrm{m}} 2^{\mathrm{c}}\left({ }^{\circ} \mathrm{C}\right)$ & $\% \mathrm{X}_{\mathrm{c}}^{\mathrm{d}}$ & $\mathrm{T}_{\text {onset }}{ }^{\mathrm{e}}\left({ }^{\circ} \mathrm{C}\right)$ & $\mathrm{T}_{\text {peak }}{ }^{\mathrm{f}}\left({ }^{\circ} \mathrm{C}\right)$ & $\%$ Weight Loss \\
\hline Sigma-Aldrich & 167 & 144 & 19 & 230 & 262 & 99 \\
\hline Biocycle & 167 & 166 & 49 & 259 & 280 & 100 \\
\hline DCC10 & 176 & 172 & 52 & 223 & 289 & 86 \\
\hline DCC20 & 176 & 170 & 63 & 220 & 270 & 79 \\
\hline DCC40 & 176 & 172 & 52 & 219 & 292 & 82 \\
\hline FCC10 & 179 & 172 & 51 & 210 & 269 & 87 \\
\hline FCC20 & 178 & 175 & 37 & 213 & 266 & 85 \\
\hline FCC40 & 177 & 170 & 44 & 208 & 241 & 76 \\
\hline
\end{tabular}

${ }^{\mathrm{a}}$ 10: solvent ratio 10:1; 20: solvent ratio 20:1; 40: solvent ratio 40:1; ${ }^{\mathrm{b}}$ Crystalline melting temperatures first cycle; ${ }^{\mathrm{c}}$ Crystalline melting temperatures second cycle; ${ }^{\mathrm{D}}$ Degree of crystallinity; ${ }^{\mathrm{e}}$ Degradation onset temperature; ${ }^{\mathrm{f}}$ Maximum degradation temperature.

similar to those reported in the literature and this is important for its use in downstream applications. PHA biodegradability is directly influenced by the degree of crystallinity, low crystalline polymers are desirable due to their lower biodegradation times. ${ }^{18}$ PHAs with low crystallinity have desirable mechanical properties for applications in the medical field (e.g. sutures) and pharmaceutical field, e.g. controlled-release of drugs. ${ }^{3,18}$

Through TGA analysis of the recovered $\mathrm{P}(3 \mathrm{HB})$ from the DCC, the onset temperature ranged from $219-223{ }^{\circ} \mathrm{C}$ and the maximum degradation temperature varied from $270-292^{\circ} \mathrm{C}$. These values were higher than those for the polymers recovered from the FCC, the onset temperature ranged from $208-212^{\circ} \mathrm{C}$, and the maximum degradation temperature varied from $241-269^{\circ} \mathrm{C}$. These results indicate that the polymers recovered from the DCC were more temperature resistant, enhancing their processability range and allowing safer handling of the biopolymer.

The observed weight loss ranged from $76-87 \%$ but it was not directly related to the biomass state (DCC or FCC) or the solvent ratios used during the extraction step. In most of the $\mathrm{P}(3 \mathrm{HB})$ samples, thermal degradation occurred in only one stage of weight loss, indicating that the process occurred through a single degradation mechanism. ${ }^{46}$ However, we observed two stages of degradation when the extraction process used a 40:1 solvent ratio. This phenomenon is usually associated with the presence of impurities carried over from the extraction process, e.g. cellular residue. However, the methodologies that employ the largest ratio of solvent to biomass during the extraction process should, in theory, have resulted in greater purification and higher polydispersion of the polymer.

\section{Gel Permeation Chromatography (GPC)}

The molar mass $(\mathrm{Mm})$ of the polymers recovered from the DCC were lower than those recovered from the FCC. The values ranged from 2.9 to $3.3 \times 10^{5} \mathrm{Da}$ for the DCC polymers and 5.1 to $6.3 \times 10^{5}$ Da for the FCC polymers, see Table 3 . The Mm of native $\mathrm{P}(3 \mathrm{HB})$ produced by bacteria usually ranges from $1 \times 10^{4}$ to $3 \times 10^{6} \mathrm{Da}$, with a polydispersion $(\mathrm{Mm} / \mathrm{Mn})$ value of approximately 2.0 , in agreement with the finding of this study. ${ }^{47} \mathrm{The} \mathrm{Mm}$ of a PHA is a factor of extreme importance because it directly affects the mechanical strength of the polymer, as well as the swell ability, hydrolysis and consequently the rate of biodegradation, which is also related to crystallinity. Thus, for the development of a PHA controlled-release systems, the polymer should have a lower Mm. ${ }^{48}$ Furthermore, PHAs with low Mm can be used as components to build various architectures, such as block and grafting copolymers, as they can provide increased flexibility. ${ }^{49,50} \mathrm{In}$ addition, we observed that the polymers extracted with a 40:1 solvent ratio showed increased polydispersion regardless of the biomass state used in the extraction process.
Table 3. Polydispersion data and average $\mathrm{Mm}$ for recovered $\mathrm{P}(3 \mathrm{HB})$ from DCC or FCC using different solvent ratios

\begin{tabular}{lccc}
\hline \multirow{2}{*}{ Samples $^{\mathrm{a}}$} & \multirow{2}{*}{$\begin{array}{c}\text { Polydispersion } \\
(\mathrm{Mm} / \mathrm{Mn})\end{array}$} & \multicolumn{2}{c}{ Average Molar Mass (Da) } \\
\cline { 3 - 4 } DCC10 & 2.3 & $1.4 \times 10^{5}$ & $3.2 \times 10^{5}$ \\
DCC20 & 2.1 & $1.6 \times 10^{5}$ & $3.3 \times 10^{5}$ \\
DCC40 & 2.9 & $1.0 \times 10^{5}$ & $2.9 \times 10^{5}$ \\
FCC10 & 2.2 & $2.8 \times 10^{5}$ & $6.3 \times 10^{5}$ \\
FCC20 & 2.4 & $2.7 \times 10^{5}$ & $6.3 \times 10^{5}$ \\
FCC40 & 3.7 & $1.4 \times 10^{5}$ & $5.1 \times 10^{5}$ \\
\hline
\end{tabular}

${ }^{\mathrm{a}}$ 10: solvent ratio $10: 1 ; 20$ : solvent ratio $20: 1 ; 40$ : solvent ratio 40:1.

\section{CONCLUSION}

The present study found that the conventional method of chemical recovery for $\mathrm{P}(3 \mathrm{HB})$ using chloroform and heating could be improved by reducing the heating time by $75 \%$ and using a solvent:biomass ratio of 40:1. Furthermore, recovery of the $\mathrm{P}(3 \mathrm{HB})$ using a liquid-liquid phase separation step led to faster separation times and lower costs. Although the use of fresh biomass during the extraction phase may be beneficial because of the lower crystallinity of the recovered $\mathrm{P}(3 \mathrm{HB})$, using the dried biomass significantly improved the yield from $18 \%$ to $98 \%$. In addition, the biomass state affected the thermal characteristics and the molar weight of the recovered $\mathrm{P}(3 \mathrm{HB})$.

\section{ACKNOWLEDGMENTS}

We gratefully acknowledge the financial support received from the funding agencies CAPES and FAPERGS. We thank A. B. Moura, Bacteriology Laboratory, FAEM, UFPel for providing the Ralstonia solanacearum RS strain. We also thank S. M. Kesserlingh, PHB Industrial, for carrying out the molar mass analysis.

\section{REFERENCES}

1. Reddy, C. S. K.; Ghai, R.; Rashmi, T.; Kalia, V. C.; Bioresour. Technol. 2003, $87,137$.

2. Luengo, J. M.; García, B.; Sandoval, A.; Naharroy, G.; Oliveira, E. R.; Curr. Opin. Microbiol. 2003, 6, 251.

3. Serafim, L. S.; Lemos, P. C.; Levantesi, C.; Tandoi, V.; Santos, H.; Reis, M. A. M.; J. Microbiol. Methods 2002, 51, 1.

4. Kunasundari, B.; Sudesh, K.; Express Polym. Lett. 2011, 5, 620.

5. Madison, L. L.; Huisman, G. W.; Microbiol. Mol. Biol. Rev. 1999, 63, 21. 
6. Chanprateep, S.; J. Biosci. Bioeng. 2010, 110, 621.

7. Rodríguez-Contreras, A.; Koller, M.; Dias, M. M. S.; Calafell-Monfort, M.; Braunegg, G.; Marqués-Calvo, M. S.; J. Appl. Microbiol. 2013, 114, 1378 .

8. Sathish, A.; Glaittli, K.; Sims, R. C.; Mille, C. D.; J. Polym. Environ. 2014, 22, 272.

9. Rodríguez-Contreras, A.; Koller, M.; Dias, M. M. S.; Calaffel-Monfort, M.; Braunegg, G.; Marqués-Calvo, M. S.; Biochem. Eng. J. 2015, 94, 50 .

10. Ramsay, J. A.; Berger, E.; Voyer, R.; Chavrie, C.; Ramsay, B. A.; Biotechnol. Tech. 1990, 8, 589.

11. Byrom, D.; Trends Biotechnol. 1987, 5, 246.

12. Pereira, D. D.; Moura, A. B.; Silva, E. G.; Kunzler, D. P.; Cienc. Rural 2001, 6, 22.

13. Rodrigues, A. A.; Macagnan, K. L; Santos, B. C.; Alves, M. I.; Moura, A. B.; Peralba, M. C. R.; Oliveira, P. D.; Pinto, L. S.; Dellagostin, O. A.; Moreira, A. S.; Vendruscolo, C. T.; Revista Brasileira de Tecnologia Agroindustrial 2015, 9, 1771.

14. Hayward, A. C.; Rev. Phytopathol. 1991, 29, 65.

15. Peeters, N.; Guidot, A.; Vailleau, F.; Valls, M.; Plant. Pathol. 2013, 14, 651.

16. Raza, W.; Ling, N.; Yang, L.; Huang, Q.; Shen, Q.; Sci. Rep. 2016, 6, 24856.

17. Lee, I. Y.; Kim, G. J.; Choi, D. K.; Yeon, B. K.; Park, Y. H.; J. Ferment. Bioeng. 1996, 81, 255.

18. Lee, S. Y.; Biotechnol. Bioeng. 1995, 49, 1.

19. Kessler, B.; Witholt, B.; J. Biotechnol. 2001, 86, 97.

20. Jacquel, N.; Lo, C. W.; Wei, Y. H.; Wu, H. S.; Wang, S. S.; Biochem. Eng. J. 2008, 39, 15.

21. Quines, L. K. M.; Ienczak, J. L.; Schmidt, M.; Zanfonato, K.; Rodrigues, M. I.; Schmidell, W. Quim. Nova 2015, 38, 214.

22. Fiorese, M. L.; Freitas, F.; Pais, J.; Ramos, A.; Reis, M.; Eng. Life Sci. 2009, 9, 454

23. Schaad, N. W.; Jones, J. B.; Chun, W.; Laboratory guide for identification of plant pathogenic bacteria, $3^{\text {th }}$ ed., APS Press, 2001.

24. Jeanes, A.; Food Technol. 1974, 28, 34

25. Lelliot, R. A.; Stead, D. E.; Methods for the diagnosis of bacterial diseases of plants, $1^{\text {th }}$ ed., Palo Alto: Blackwell, 1987.

26. Vanin, M.; Santana, C. C.; Torriani, I. L.; Privelic, T.; Duek, E. A. R.; Polim.: Cienc. Tecnol. 2004, 14, 187

27. Dalcanton, F.; Dissertação de Mestrado, Universidade Federal de Santa Catarina, Brasil, 2006.

28. Braunegg, G.; Sonnleitner, B.; Lafferty, R. M.; Appl. Microbiol. Biotechnol. 1978, 6, 29
29. Brandl, H.; Gross, R. A.; Lenz, R. W.; Fuller, R. C.; Appl. Environ. Microbiol. 1988, 54, 1977.

30. Crochemore, A. G.; Mattos, M. L. T.; Vendruscolo, C. T.; Castro, L. A. S.; Moreira, A. S.; Afr. J. Biotechnol. 2012, 11, 15144.

31. Gogolewski, S.; Jovanovic, M.; Perren, S. M.; Dillon, J. G.; Hughes, M. K.; J. Biomed. Mater. Res. 1993, 27, 1135.

32. Anderson, A. J.; Dawes, E. A.; Microbiol. Rev. 1990, 54, 450.

33. Jendrossek, D.; Selchow, O.; Hoppert, M.; Appl. Environ. Microbiol. 2007, 73, 586.

34. Domingos, L. F.; Dissertação de Mestrado, Universidade Federal de Santa Catarina, Brasil, 2012.

35. Khardenavis, A. A.; Kumar, M. S.; Mudliar, S. N.; Chakrabarti, T.; Bioresour. Technol. 2006, 98, 3579.

36. Lugg, H.; Sammons, R. L.; Marquis, P. M.; Hewitt, C. J.; Yong, P.; Paterson-Beedle, M.; Biotechnol. Lett. 2008, 30, 481.

37. Silverstein, R. M.; Bassler, G. C.; Morri, L. T. C.; Spectrometric Identification of Organic Compounds, $4^{\text {th }}$ ed., John Wiley e Sons: New York, 1981 .

38. Stuart, B. H.; Infrared Spectroscopy: Fundamentals and Applications, John Wiley e Sons: London, 2004

39. Pavia, D. L.; Lampman, G. M.; George, S.; Kriz, G. S.; Vyvyan, J. R.; Introdução à Espectroscopia, $4^{\mathrm{a}}$ ed, Cencgage Learning: São Paulo, 2010

40. Valappil, S. P.; Misra, S. K.; Boccaccini, A. R.; Keshavarz, T.; Bucke, C.; Roya, I.; J. Biotechnol. 2007, 132, 251.

41. Yezza, A.; Halasz, A.; Levadoux, W.; Hawari, J.; Appl. Microbiol. Biotechnol. 2007, 77, 269.

42. Chaijamrus, S.; Udpuay, N.; Agricultural Engineering International: the CIRGE journal 2008, 7, 30.

43. Hong, S. G.; Lin, Y. C.; Lin, C. H.; React. Funct. Polym. 2008, 68, 1516.

44. Khanna, S.; Srivastava, A. K.; Process Biochem. 2005, 40, 607.

45. Reddy, S. V.; Thirumala, M.; Mahmood, S. K.; World J. Microbiol. Biotechnol. 2009, 25, 391 .

46. Duarte, M. A. T.; Júlio, C. F.; Martins, E. S.; Pezzin, S. H.; Rev. Mater. 2004, 9, 386

47. Sudesh, K.; Abe, H.; Doi, Y.; Prog. Polym. Sci. 2000, 25, 1503.

48. Montoro, S. R.; Shigue, C. Y.; Sordi, M. L. T.; Santos, A. M.; Ré, M. I.; Polim.: Cienc. Tecnol. 2010, 20, 19.

49. Zhang, X.; Yang, H.; Liu, Q.; Zhenh, Y.; Xie, H.; Wang, Z.; J. Polym. Sci., Part A: Polym. Chem. 2005, 43, 4857

50. Lao, H.; Renard, E.; Linossier, I.; Langlois, V.; Vallée-Rehel, K.; Biomacromolecules 2007, 8, 416. 